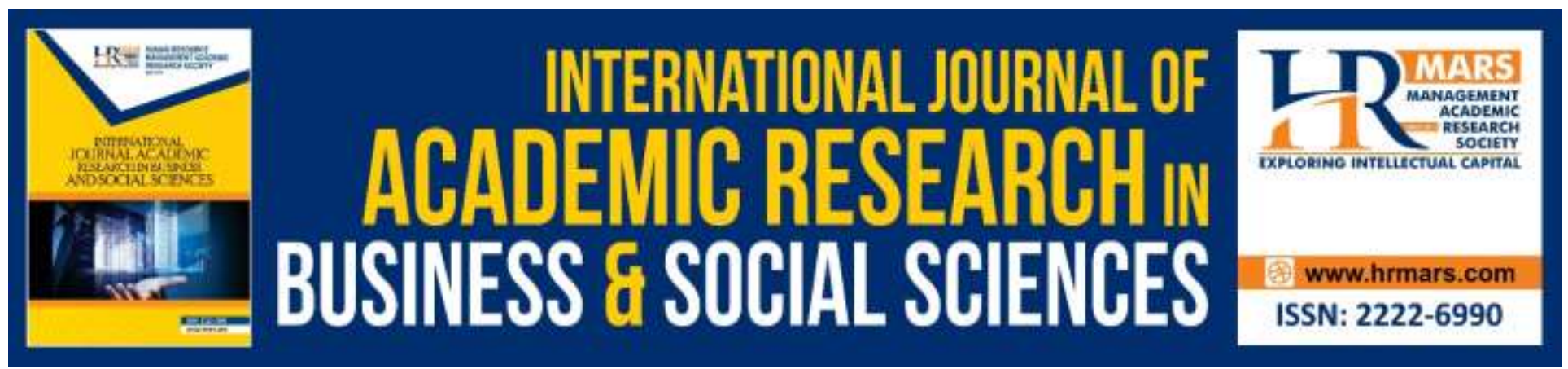

\title{
Fake News: Logical Reasoning Ability and Students Vulnerability
}

Jerald C. Moneva, Rena Mae N. Yaun, Ismaelita Desabille

To Link this Article: http://dx.doi.org/10.6007/IJARBSS/v10-i3/7090

DOI:10.6007/IJARBSS/v10-i3/7090

Received: 02 February 2020, Revised: 22 February 2020, Accepted: 12 March 2020

Published Online: 29 March 2020

In-Text Citation: (Moneva et al., 2020)

To Cite this Article: Moneva, J. C., Yaun, R. M. N., \& Desabille, I. (2020). Fake News: Logical Reasoning Ability and Students Vulnerability. International Journal of Academic Research in Business and Social Sciences, 10(3), 761-774.

Copyright: (C) 2020 The Author(s)

Published by Human Resource Management Academic Research Society (www.hrmars.com)

This article is published under the Creative Commons Attribution (CC BY 4.0) license. Anyone may reproduce, distribute, translate and create derivative works of this article (for both commercial and non-commercial purposes), subject to full attribution to the original publication and authors. The full terms of this license may be seen at: http://creativecommons.org/licences/by/4.0/legalcode

Vol. 10, No. 3, 2020, Pg. 761 - 774

http://hrmars.com/index.php/pages/detail/IJARBSS

JOURNAL HOMEPAGE

Full Terms \& Conditions of access and use can be found at http://hrmars.com/index.php/pages/detail/publication-ethics 


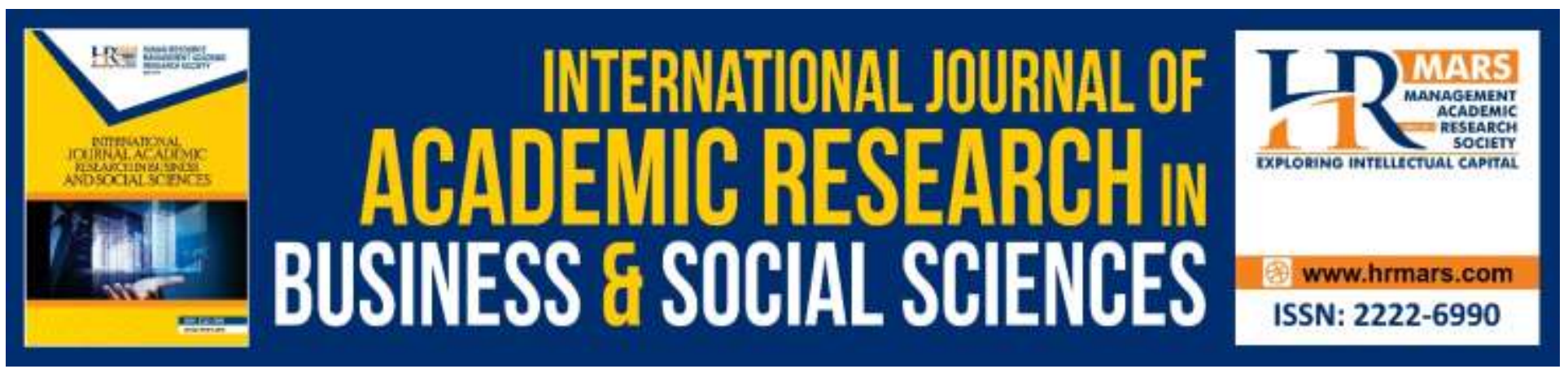

\title{
Fake News: Logical Reasoning Ability and Students Vulnerability
}

\author{
Jerald C. Moneva, Rena Mae N. Yaun, Ismaelita Desabille \\ Mandaue City Division- Department of Education, Mandaue City, Cebu Philippines, Senior High \\ School, Jagobiao National High School, Jagobiao Mandaue City, Cebu Philippine \\ Email: freezingfire1979@gmail.com, renamaeyaun16@gmail.com, \\ ismaelita.desabille@deped.gov.ph
}

\begin{abstract}
Logical reasoning ability refers to the students' ability to understand logical work through concepts and problems. Logical reasoning is one of the fundamental skill that is used for effective thinking. Fake news is a spread of inaccurate information in the internet and other forms of media. It is made either to misinform or deceive the reader most inevitably the students. The researcher aims to assess the relationship between logical reasoning ability and students' vulnerability towards fake news. There are 240 respondents to answer the given survey questionnaire. All grade 11 and grade 12 students in the strand of STEM, HUMSS, GAS, ABM and TVL-Drafting in Jagobiao National High School- Senior High School Department were requested to answer the questionnaire in rating scale. The methodology in this study is quantitative survey using a check-list and NCAE result to gather data. The data have been analyzed using chi-square to determine if there is an association between logical reasoning ability and students' vulnerability towards fake news. The result showed that there are no significant association between logical reasoning ability and students vulnerability towards fake news. Based on these findings, it was recommended that the parents, teachers, and school should put their guard on their children for them not to be easily deceit by fake news. It has been recommended that they should provide facts to students and encourage them to combat against the spread of false information.
\end{abstract}

Keywords: Fake News, Logical Reasoning, Ability, Students, Vulnerability

\section{Introduction}

Introduction Fake news is a spread of false stories in the internet and other forms of media. Fake news has no basis but seems factually accurate because such content is not questioned or reviewed. Logical reasoning or logic is the process of using rational in solving a problem. It is one of essential skills use for effective thinking. Logic is always reasonable and requires a person's deeper understanding in any situations that can be mathematical equations or real life experiences. 
INTERNATIONAL JOURNAL OF ACADEMIC RESEARCH IN BUSINESS AND SOCIAL SCIENCES Vol. 10, No. 3, March, 2020, E-ISSN: 2222-6990 @ 2020 HRMARS

Meanwhile, student's vulnerability refers to the students who get easily affected by unbelievable and false information.

The researchers believed that logical reasoning ability has a great influence on how students identify fake news. Students misjudged immediately because they only focused on the appearance of information rather than its content. Fake news can easily spread through the use of gadgets and it is one of the disadvantages in today's technology advancement. Now, as people engage more in social media websites, they will see trends and see various post that include news, pictures, and many others which can directly affect their mindset towards certain things, people, scenarios to a great extent. Due to the advancement of technology, fake news has a wide reach to the internet and most people fall for such news because it seems factual. Hence, students get easily influenced by the fake news because they still have young minds and little knowledge on factual data. With unreliable news and cynical reports feed on the young consumers, students misjudged the concept of most significant events in media and cyber world. The importance of distinguishing reports is for the students to put their guard on the untruthful posts and focus on educational articles with facts. Furthermore, the prominences of news are oftentimes neglected because nowadays, it is hard to identify which one is to believe. The widespread of fake news is causing misinformation to young adults keeping them apart from the truth. In addition, the internet with great advantage of easy communication also put youngsters to vulnerability. Most students depend on researchers and most researchers are falsified making data on the internet unreliable. Logical thinking ability in understanding data should be taught to students as they play a great part on the media. Logical reasoning of students is very important because it gives them the capability to understand what they have read and been seen. In the world of internet, students with great thinking ability will never be in a state of vulnerability as they know how to distinguish false from facts. Logical thinking is essential for students to evaluate news and feed their mind with resourceful information. To never underestimate the amount of fake news that reaches them this is alternately gullible and cynical. Students must learn to discern facts from fiction and truth from lies. Moreover, students have to verify sources, questions, and think logically. An ability to succeed as a student and functional adult will depend on students' ability to balance truth and confidence with a healthy skepticism.

According to Bouhnik and Giat (2009) most students do not acquire the proper skills needed in today's information era and many students do not have the ability to search efficiently for information. According to Lubis and Nasution (2017) students may already experience much about logic but it is not assurance that they have better understanding about logic. According to Sezen and Bulbul (2011) logic determines the right thinking which is also known as a tool for effective thinking.

Consequently, this study aims to assess the association of the students logical reasoning ability and students' vulnerability towards fake news among students in Jagobiao National High School.

\section{Theoretical Background}

Howard Gardner's Multiple Intelligence Theory

This study is supported by Howard Gardner's Multiple Intelligence Theory, proposed by Howard Gardner (1983). The theory tackled about the different types of intelligence that relate to a person's uniquely capabilities and ways they prefer to establish intellectual abilities. By knowing these 
INTERNATIONAL JOURNAL OF ACADEMIC RESEARCH IN BUSINESS AND SOCIAL SCIENCES Vol. 10, No. 3, March, 2020, E-ISSN: 2222-6990 @ 2020 HRMARS

intelligences, student's will know how to develop their strengths and confidence to improve fields in which they are not strong.

Verbal-linguistic intelligence is the capacity to understand the complexities of sentence structure, word structure, meaning and pronunciation. People with linguistic intelligence love words and has reach of vocabularies.

Logical-mathematical intelligence is the capacity to process information through logic and reason. People with logical mathematical intelligence often seeks evidence, facts, accuracy in what they do.

Spatial-visual intelligence is the capacity to be aware of their surroundings and are good at remembering images. People with spatial visual intelligence learn well through the use of visual arts, drawings and pictures.

Bodily-kinesthetic intelligence is the capacity to learn through movement and experimentation. People with kinaesthetic intelligence perform well in dancing, recreational activities and many others that exert physical efforts.

Musical intelligence is the capacity to make sound and tone easily. Some people with musical intelligence are good at singing, composing songs and playing instruments.

Interpersonal intelligence is the capacity to thrive with social interaction. Interaction with people and lively discussions is what how a person who has interpersonal intelligence learn.

Intrapersonal intelligence is the capacity to figure out their own feelings. People with intrapersonal intelligence enjoy making journals because it helps them learn about themselves and also good at helping others to know and understand themselves.

Naturalist intelligence is the capacity to be sensitive and appreciate nature. People with naturalist intelligence love recognizing and categorizing plants, animals, and other object in nature.

Existential intelligence is the capacity of human mind to think about the existence of life, death and beyond. People with existential intelligence have a hard belief in what they see as true. Proofs of their beliefs may or may not be existed but they know what they believe and they stand by it.

There are nine intelligences of Howard Gardner but logical-mathematical is much related to the study. Logical-mathematical can be classified as problem solving and calculations. Problem solving involves organizing and investigating while calculations involves numbers. A person who possesses this skill has the capacity to think for themselves, question and find truth. Their decisions are based on factual data therefore they do not easily influence by unrealistic reports.

In general, a student who has logical-mathematical intelligence can be good at distinguishing unbelievable reports for they always seek accuracy in their work but there is also a possibility that they get vulnerable by unrealistic information. It may depend on students' perception or situation.

\section{Purpose Statement}

The study intends to determine the relationship between logical reasoning ability and students' vulnerability towards fake news. Specifically, the study seeks to answer the following sub-problem:

1. What is the profile of National Career Assessment Examination results of the students?

2. What is the students level of vulnerability towards fake news?

3. Is there any relationship between logical reasoning ability and students' vulnerability towards fake news?

Hypothesis: 
INTERNATIONAL JOURNAL OF ACADEMIC RESEARCH IN BUSINESS AND SOCIAL SCIENCES

Vol. 10, No. 3, March, 2020, E-ISSN: 2222-6990 (C) 2020 HRMARS

HO: There is no relationship between logical reason ability and students' vulnerability towards fake news

$\mathrm{H} 1$ : There is a relationship between logical reasoning ability and students' vulnerability towards fake news

\section{Significance of the Study}

The results of the study will be a great benefit to the following:

The study will provide information to the students regarding their logical reasoning ability in dealing with fake news. They will know the extent when they have logical reasoning with fake news. They will also know the level of their vulnerability.

The given data will guide the teachers on what to do to improve the students logical reasoning ability by teaching them to cite sources, questions and verify the validity of information. The teacher will be able to understand why some student fall for such fake news and later on, help them.

Like the teachers, the parents and guardians too will understand why their children can be easily deceit by fake news. The given data would help them do some precautionary measures to help their sons and daughters from believing false information.

The result of this study will help the community strengthen their knowledge on fake news. They will help out those young individuals to have proper reasoning to avoid the widespread of fake news. The community will give advice to youngsters to always check the validity of what they have read and been seen. Thus, it will lessen their vulnerability towards fake news.

This research will be a useful reference for the future researchers who would plan to make any related study about logical reasoning ability and students vulnerability towards fake news. They will gain new insights regarding on how students behave in today's information era. This study will give them proper guidelines on how logical reasoning influences the students in identifying fake news.

\section{Definition of Terms}

The researcher gives meaning to the following terminologies: Logical Reasoning Ability is taken from

National Career Assessment Examination (NCAE) and it refers to the process of using rational in solving a problem.

Students Vulnerability refers to the student who believes fake news easily.

Fake News is false information coming from any forms of media for example Facebook, Twitter, Instagram, etc.

\section{Review of Related Literature and Study}

The study "Fake News: Logical Reasoning Ability and Students' Vulnerability" was supported by several articles.

To enhance the students' capacity to think rationally it is required for them to have a basic thinking aptitudes at their secondary school (Bouhnik \& Giat, 2009). Consistent thinking may improve the learning of students by teachers instructing strategies (Noor, Hassan \& Ahmad, 2017). School 
INTERNATIONAL JOURNAL OF ACADEMIC RESEARCH IN BUSINESS AND SOCIAL SCIENCES Vol. 10, No. 3, March, 2020, E-ISSN: 2222-6990 @ 2020 HRMARS

outstandingly instructional exercises within the style of collective argument analysis ends up in important development within the analytical reasoning adeptness of learners and also within the sensible understanding of information (Cullen, Fan, Brugge \& Elga, 2018). In teaching logical reasoning, understudies can be prepared together with the instructing materials that gives direct encounters and useful issues (Yenilmez, Sungur \& Tekkaya, 2017).

Teaching logic in secondary school gives a superb chance to learners to grow elevated level thinking abilities with the goal that they can apply them in real life circumstances (Marou \& Kalospyros, 2011). Students will perform better academically and will be set up for their rigors and scholarly expectations of their next college journey if they build up the capacity to think basically and their present secondary school (Changuong, Sukkamart \& Sisan, 2018).

Students' emotions have something to do with their legitimate thinking (Jung, Wranke, Hamburger \& Knauff, 2018). Sometimes the content itself will contribute the complexity of the issue, however its role will rely upon the idea of task given (Yang \& Johnson-Laird, 2002). Students decision about what's the reality and lie is hard to the point that in any event, when they are inspired to do it, students frequently struggle to comprehend it unless they have some information on fundamental logical instruments (Epp, 2003). Their thinking does not show a better comprehensions of the conditions of the circumstances even a few understudies may know the right answer (Lubis \& Nasution ,2017). Students are expected to have logical reasoning because legitimate thinking is not gender-sensitive (Agah, 2016).

Cognitive style predicts day by day issue and this relationship impacted by consistent thinking (Perzuti, Artistico, Chirumbolo, Picones \& Doward, 2014). A portion of the understudies go to the school with logical approach and some do not. The significant point here is that, learners already build their intellectual aptitudes at the age of 16-18 and they assumed to think in logical way and ought to do objects and abstracts (Bektashi \& White, 2012). Thus, it is necessary for the students to participate in exercises that will improve their capacity to think sensibly (Ongcoy, 2016). Since logic and basic reasoning are valid and sound thinking this means to live without these is to live without reason (Emeka \& Shukwudi, 2018).

Exposure to the facts is needed for the students before social media, search engines and memetic discordance can completely change of what has been said (Albright, 2017). According to the informative democratic standards, the inability to access information and struggling to understand false news as an issue were alarming (Scheufele \& Krause, 2018). Gossips that are refutable makes a distinctive blast that in the quantity of retweets considerably more than bits of gossip that have been demonstrated adequate or deficient (Zubiaga, Liakata, Procter, Sakhoi \& Tolmie, 2016). For instance, many of Facebook users have exposed more fake news articles in their networks (Guess, Nugler \& Tucker, 2019). Fake news is viewed on social media from different angles due to the centralized gatekeeping debate by certain influential or famous online users (Al-Rawi, 2018).

The students who conclude that fake news is more credible is the students who overstate their level of information (Pennycock \& Rand, 2018). Claims that promote disinformation who has been produced by students fail to later question and change their attitude initially (Chan, Jones, Jamieson \& Albarracin, 2017). It is so hard for readers to detect false news from true stories (Kumar \& Shah, 2018). Issues related to fake stories and exploitation in digital environment appear to be the subject of many public debate, including from the traditional media due to the internet's role in modern societies (Cunha, Caetano, Magno \& Almeida, 2018). Diffusion of misinformation by means 
INTERNATIONAL JOURNAL OF ACADEMIC RESEARCH IN BUSINESS AND SOCIAL SCIENCES

Vol. 10, No. 3, March, 2020, E-ISSN: 2222-6990 C 2020 HRMARS

of online networking is a possible risk to democracy and wider society (Alcott, Gentzkow \& Yu, 2019). Despite the fact that students are bored and cynical about official news they are not usually paying attention about current events (Marchi, 2012).

Students must rely primarily on news content and limited information relevant to society and face multiple challenges to detect false news during its life span at an early stage (Zhou \& Zabarani, 2018). Students may adapt and become less vulnerable to dissemination if they become aware of the presence of fake news on social media (Aymanns, Foerster \& Georg, 2017). Students should be encouraged that sharing of news and information can affect their socialites (Pangrazio, 2018). Early media literacy help empower students against the risk of disinformation and may therefore the best prevention (Roozenbeek \& van der Linden, 2018).

\section{Research Methodology}

This chapter discusses about the design, environment, respondents, instruments and data gathering that will be used in the research study.

\section{Design}

The study was designed to examine the descriptive correlation between logical reasoning ability and students vulnerability towards fake news.

\section{Environment}

The study will be conducted in Jagobiao National High School-Senior High School department. The Senior High School building consist of two buildings and it can be seen in the lower part of Junior High School building. The first building has six rooms while the second building has it rooms which is occupied by grade 11 and grade 12 students. The classrooms composed of the following strands: Accountancy, Business and Management (ABM), Humanities and Social Sciences (HUMSS), General Academic Strand (GAS), Science, Technological, Engineering and Mathematics (STEM), and Technical Vocational and Livelihood-Drafting (TVL-Drafting).

\section{Respondents}

The chosen respondents of the study are all Senior High School students particularly grade 11 and grade 12 students. A total of 240 respondents from Senior High Department and these are the ones who would answer the following questions to achieve the research objectives.

\section{Instruments}

The researcher used checklist-questionnaire that is composed of 1 part only. The respondents will answer a 10-item question about the level of their vulnerability towards fake news. The questionnaire is consisting of questions that are answerable by 1-5 that stands for: (1) Never; (2) Seldom; (3) Sometimes; (4) Often; and (5) Always. The researcher also used National Career Assessment Examination (NCAE) to get the students result of their Logical Reasoning Ability test which is available in the school records. 
INTERNATIONAL JOURNAL OF ACADEMIC RESEARCH IN BUSINESS AND SOCIAL SCIENCES

Vol. 10, No. 3, March, 2020, E-ISSN: 2222-6990 C 2020 HRMARS

\section{Data Gathering}

The researcher will ask permission from the school head using a transmittal letter. The respondents will be given the questionnaire and the researcher will give them enough time to answer the questions. The researcher will give appreciation to the respondents for the cooperation of the study. The data gathered by the researcher will be used for the analysis, interpretation, findings, conclusion and recommendation of the study.

\section{Statistical Treatment}

This study used weighted mean to get the mean of the level of vulnerability of the students. The study used Chi-Square test to determine whether there is significant difference between the expected frequencies and the observed frequencies in one or more categories.

\section{Presentation, Analysis and Interpretation of Data}

This chapter presents the findings, presentations, analysis and interpretations of data that aims to determine the extent of students logical reasoning and the level of their vulnerability towards fake news.

Table 1

\section{Logical Reasoning Ability}

\begin{tabular}{|l|l|l|}
\hline Category & Frequency & Percentage \\
\hline Poor & 0 & 0 \\
\hline Fair & 44 & 18.3 \\
\hline Good & 151 & 62.9 \\
\hline Logical & 44 & 18.3 \\
\hline Extraordinary & 1 & .4 \\
\hline TOTAL & $\mathbf{2 4 0}$ & $\mathbf{1 0 0}$ \\
\hline
\end{tabular}

Scale: (0-200) Poor; (201-400) Fair; (401-600) Good; (601-800) Logical; (801-1000) Extraordinary

The table above shows that out of 240 respondents, 151 of the respondents have good logical reasoning with a percentage of 62.9 percent. The respondents have poor and logical reasoning with the same percentage of 18.3 percent. The least percentage of the respodents who have extraordinary logical reasoning have a percentage of 0.4 percent. In addition, the result shows that there is no students who have very poor logical reasoning. To improve students' academic performance logical reasoning must be given an utmost importance in teaching (Noor, Hassan \& Ahmad, 2017). It requires the ability to think critically in any situations that need a creativity in solving problems and showing particular insights into possible solutions and also requires a learner to trust their abilities in doing such task (Changwong, Sukkamart \& Sisan, 2018). At the beginning of instruction, teachers need to know the extent of students' logical reasoning ability so he/she could provide the teaching materials, teaching strategies and other things that is necessary to every students to learn (Ongcoy, 2016). 
INTERNATIONAL JOURNAL OF ACADEMIC RESEARCH IN BUSINESS AND SOCIAL SCIENCES Vol. 10, No. 3, March, 2020, E-ISSN: 2222-6990 @ 2020 HRMARS

Table 2

\section{Students Vulnerability}

\begin{tabular}{|l|l|l|}
\hline Indicators & WM & Interpretation \\
\hline $\begin{array}{l}\text { 1. I believe news I just read in the internet. } \\
\text { whenever I hear a rumor. }\end{array}$ & 3.17 & Sometimes \\
\hline $\begin{array}{l}\text { 3. I believe that news does not contain any malicious distortion of truth. } \\
\text { 4. I do not use skepticism in every news I read. }\end{array}$ & 2.79 & Sometimes \\
\hline $\begin{array}{l}\text { 5. I can hardly identify news whether it is fake or factual. } \\
\text { 6. I do not ask if the news that was posted by famous personalities in } \\
\text { facebook was true. }\end{array}$ & 2.80 & Sometimes \\
\hline $\begin{array}{l}\text { 7. I do not go to the news sources if I doubt the validity of what I read. } \\
\text { 8. I do not express my opinion if my friend talks about something that is } \\
\text { trend and just go with the flow. }\end{array}$ & 2.90 & Sometimes \\
\hline $\begin{array}{l}\text { 9. I unreluctantly share a post in facebook if I find it interesting. } \\
\text { 10. I easily believe information posted by strangers in social media such as } \\
\text { facebook, instagram, and twitter.. }\end{array}$ & 3.62 & Sometimes \\
\hline Overall weighted Mean & 2.85 & Sometimes \\
\hline
\end{tabular}

Scale: (1.00-1.80) Never; (1.81-2.60) Seldom; (2.61-3.40) Sometimes; (3.41-4.20) Often; (4.21-5.00) Always.

The table above shows the overall weighted mean of level of vulnerability of the students towards fake news, weighted mean $=2.85$. it means that students are sometimes vulnerable in fake news. The statement "I believe news I just read in the internet" has the highest weighted mean with 3.17 that signify that they are sometimes vulnerable in fake news by believing the news they just read in the internet. It is more effective when people who experience falsified messages counter-argue the misinformation that reaches them (Chan, Jones, Jamieson \& Albaraccin, 2017). "I unreluntly share a post in Facebook If I find it interesting" has the second highest weighted mean with 3.11 which signify that students are sometimes vulnerable by being unreluctant to share a post in Facebook. The third highest weighted mean of 2.99 state that "I can hardly identify news whether it is fake or factual" it signifies that sometimes they can hardly identify news whether it is fake or factual. The statement "I judge quickly without examining the truthfulness of its content whenever I hear a rumor" has the least weighted mean of 2.54 which means that they seldom judge without examining the truthfulness of the rumor. "I easily believe information posted by strangers in social media such as in Facebook, Instagram, and Tweeter" has the second lowest mean of 2.62 which means that they sometimes believe information being posted by strangers. Students often got their news from their social networks though they can be informed by their peer, family, and strangers (Marchi, 2017). Lastly, the indicator that has 2.6 weighted mean statement that "I do not use skepticism in every news i read" this signifies that they are sometimes skeptical in every news i read. Primarily, based misinformation can be determined by means of matching it towards a knowledge based statistics (Kumar and Shah, 2018). 
INTERNATIONAL JOURNAL OF ACADEMIC RESEARCH IN BUSINESS AND SOCIAL SCIENCES

Vol. 10, No. 3, March, 2020, E-ISSN: 2222-6990 @ 2020 HRMARS

Table 3

Frequency of Level of Vulnerability of Students

\begin{tabular}{|l|l|l|}
\hline Category & Frequency & Percentage \\
\hline Completely Vulnerable & 4 & 1.7 \\
\hline Vulnerable & 79 & 32.9 \\
\hline Moderately Vulnerable & 144 & 60.0 \\
\hline Slightly Vulnerable & 13 & 5.4 \\
\hline Not Vulnerable & 0 & 0 \\
\hline TOTAL & 240 & 100 \\
\hline
\end{tabular}

The table above shows that out of 240 respondents, 144 of the respondents are moderately vulnerable towards fake news with a percentage of 60 percent. The second highest percentage is 32.9 percent, means that the respondents are vulnerable. The respondents are slightly vulnerable with a percentage of 5.4 percent. While, 1.7 percent of the respondents are completely vulnerable towards fake news. The respondents are not totally vulnerable towards fake news with zero percent. The spread of misinformation can be influenced by network connectivity (Foerster \& Georg, 2017). Students who experienced fake news increases in social media such as Facebook and Twitter through the end of the year (Alcott, Gentzkow \& Yu, 2019). However, by prioritizing content or subject that are worth checking, studens ability in identifying worthy content will improve the efficiency of fake news detection (Zhou \& Zafarani, 2018).

\section{Table 4}

Fake news: Logical Reasoning Ability

\begin{tabular}{|l|l|l|l|}
\hline & Value & df & Asymp. Sig (2-sided) \\
\hline Pearson Chi-square & $5.653 a$ & 9 & .774 \\
\hline N of Valid Cases & 240 & & \\
\hline
\end{tabular}

The table shows that there is no significant association between logical reasoning ability and students vulnerability towards fake news because the significant value is .774 which is greater than the alpha 0.05 . The decision of the result is failed to reject the hypothesis $(\mathrm{H})$. Though student possess adequate logical reasoning it does not prevent them from being vulnerable to fake news. Sometimes, teaching logic does not influence students logical reasoning ability (Epp, 2003). Students tend to be tolerant of refutable rumours (Zubiaga, Liakata, Procter, Sak Hoi \& Tolmie, 2016). However, students become vulnerable to fake due to lack of reasoning (Pennycook \& Rand, 2018).

\section{Summary of Findings, Conclusion, Recommendation}

This chapter presents the summary and the major findings of the study. Based on these findings, the conclusions are made and recommendations were suggested. 
INTERNATIONAL JOURNAL OF ACADEMIC RESEARCH IN BUSINESS AND SOCIAL SCIENCES

Vol. 10, No. 3, March, 2020, E-ISSN: 2222-6990 ¿ 2020 HRMARS

\section{Summary of Findings}

The data reveals that most of the Senior High School students has good logical reasoning. Therefore, a student who may have or may not have high logical reasoning ability can still be influenced by unrealistic information.

The result of overall mean has been interpreted as sometimes. Students vulnerability of fake news may depend on the situations they are into.

There was no positive correlation between logical reasoning ability and students' vulnerability towards fake news. Based on the findings, logical reasoning ability does not measure the vulnerability of Senior High School students.

\section{Conclusions}

Howard Gardner who proposed the multiple intelligence theory mentions that logicalmathematical intelligence is the students' capacity to process information through logic and reason. Students who possess this skill often seeks evidence, facts, accuracy in their work. Meanwhile, fake news becomes alarming in school and social media. Some high school students do not know how to identify the credibility of information in the internet. Since it becomes difficult for students to discern fact from fiction, they immediately judge the content of a particular thing without examining its truthfulness. Logical reasoning in this situation is very important skill that every student should possess for it enables them to identify and interpret the complexity of a situation. Good judgement enables students to think rationally and also decides student's prescient course of action (Emeka \& Chukwudi, 2018). On the contrary, even if they possess adequate logical reasoning ability it is not an assurance that they could avoid the fake news that reaches them. However, the result of the study reveals that logical reasoning ability does not impacted student's susceptibility in dealing false news. The absence of counter-evidence is one of the common reasons why student support unverified rumor (Zubiaga, Liakata, Procter, Sak Hoi \& Tolmie, 2016). Students logical reasoning can be broaden by familiarizing abstract and logical formulas and applying them instinctively in any logical situations (Epp, 2003).

\section{Recommendations}

Based in the finding and discussion of this study, the researcher made the following recommendations:

1. Students still need to understand and know more about the importance of distinguishing false news.

2. Parents should pay attention regarding on how their children behave in today's information era and do some precautionary measures to lessen the vulnerability of their children.

3. The school should be aware on students' behavior in dealing with fake news. The school should provide facts to students and encourage them to fight against the spread of inaccurate information. 4. Future researchers need to study more about the relations of human reasoning and their vulnerability in dealing with fake news. 
INTERNATIONAL JOURNAL OF ACADEMIC RESEARCH IN BUSINESS AND SOCIAL SCIENCES

Vol. 10, No. 3, March, 2020, E-ISSN: 2222-6990 @ 2020 HRMARS

\section{References}

Agah, J. J., \& Lamido, S. (2015). Determinants of students logical reasoning and mathematics achievement. Journal of Literature, Languages and Linguistics, 5(5), 40-44. https://www.iiste.org/journals/index.php/JLLL/article/view/17781

Albright, J. (2017). Welcome to the era of fake news. Media and Information, 5(2), 87- 89. Doi: $10.17649 / \mathrm{mac}-\mathrm{V} 5 \mathrm{i} 2.977$

Alcott, H., Gentzkow, M., \& Yu, C. (2019). Trends in the diffusion of misinformation on social media. Research and Politics, 6(2), 1-8. Doi:10.117712053/1680/19848554

Al-Rawi, A. (2018). Gatekeeping fake news discourses on mainstream media versus social media. Social Science Computer Review, 37(6), 1-17. Doi:10.117710894439318795849

Aymanns, C., Foerster, J., \& George, C.P. (2017). Fake news in social networks. arXiv preprint: 1708.06233. doi:10.2139/ssrn.3023320.

Bektasli, B., \& White, A. L. (2012). The relationship between logical thinking, gender, and kinematics graph interpretation skills. Egitim Arastimalari-Eurosian Journal of Educational Research. 48, 1-20. https://eric.ed.gov/?id=EJ1057377

Bouhnik, D., \& Giat, Y. (2009). Teaching high school students applied logical reasoning. Journal of Information Technology Education: Innovations in Practice, 8(1), 1-16. Doi: 10.28945/169

Chan, M. S., Jones, C. R., Jamieson, K. H. \& Albarracin, D. (2017). Debunking: A meta-analysis of psychological efficacy of messages countering misinformation. Psychological Science, 28(11), 1531-1546. Doi: 10.117/0956797617714579

Changwong, K., Sukkamart, A., \& Sisan, B. (2018). Critical thinking skill development: Analysis of a new learning management model for Thai high schools. Journal of International Studies, 11(2), 37-38.

Cullen, S., Fan, J., Van de Brugge, E. \& Elga, A. (2018). Improving the analytical reasoning and argument understanding: A quasi-experimental field of study of argument visualization. NPT Science of Learning, 3(1), 1-6. https://www.nature.com/article/541539-018-0038-5

Cunha, E., Magno, G., Caetano, J., Teixeira, D., \& Almeida, V. (2018). Fake news as we feel it: Perception and conceptualization of the term fake news in the media. International Conference on Social Informatics, 151-166. https://arxiv.org/abs/1807.06926

Epp, S. (2003). The role of logic and teaching proof. The American Mathematical Monthly, 110(10), 886-899. Doi:10.1080/00029890.2003.1192009

Emeka, C. G., \& Chukwudi, E. E. (2018). Logic and critical thinking: The missing link in higher education in Nigeria. International Journal of History and Philosophical Research, 6(3), 1-13. https://www.eajournals.org/journals/international-journal-of-history-and-philosophicalresearch-ijhphr/vol-6-issue-3-july-2018/

Guess, A., Nagler, J., \& Tucker, J. (2019). Less than you think: Prevalence and predictors of fake news dissemination on Facebook. Science Advances, 5(1), 1-8. Doi: 10.1126/sciadv.aau4586

Jung, N., Wranke, C., Hamburger, K., \& Knauff, M. (2014). How emotions affect logical reasoning: Evidence from experiments with mood-manipulated participants, spider phobics, and people with exam anxiety. Frontiers in Psychology, 5, 570, 1-12. Doi: 1-.3389/fpsyg.2014.00570

Kumar, S., \& Shah, N. (2018). False information on web and social media: A survey, 1(1), 1-35. https://doi.org/10.1145/nnnn-nnn-nnnn-nnn

Lubis, A., \& Nasution, A. A. (2017). How do higher-education student use their initial 
INTERNATIONAL JOURNAL OF ACADEMIC RESEARCH IN BUSINESS AND SOCIAL SCIENCES

Vol. 10, No. 3, March, 2020, E-ISSN: 2222-6990 @ 2020 HRMARS

understanding to deal with contextual logic-based problems in discrete mathematics?. International Education Studies, 10(5), 72-83. https://doi.org/10.5539/ies.vlon-5p72

Marchi, R. (2012). With Facebook, blogs, and fake news teens reject journalistic objectivity. Journal of Communication Inquiry, 36(3), 246-262. Doi: 10.117/0196859912458700

Marou, A. P., \& Kalospyros, N. A. (2011). The role of logic in teaching, learning, and analyzing proof. In Congress of the European for Research in Mathematics Education, 7, 9.https://scholar.google.com/scholar?custer $=71829566596279252 \&$ hl=en\&as_sdt=2005\&sc iodt-o,5\#d=gs_9abs\&u=\%23p\%301\#toPRrm9wk

Noor, N. F. A. M., Hassan, A., \& Aniza, N. (2017). Relationship between emotional, intelligence, motivation and logical reasoning towards academic achievement among secondary school students. International Journal of Academic Research in Business and Social Sciences, 7(7), 196-216. Doi: 10.6007/IJARBSS/v7-i14/3662

Ongcoy, P. J. B. (2016). Logical reasoning abilities of junior high school students in the province of Cotabato, Philippines. Acia Pacific Journal of Multidisciplinary Research, 4(4), 18-21. https://www.apjmr.com.wp-content/uploads/2016/10APJMR-2016.4.4.2.03.pdf\&ved2ahUKEwiQ8Nj/AhW7L6YKHWzSB6kQFjAAegQIBhAB\&usg=AOvVawOPrXrmLILbj37mhIU=Ao 4F\&cshid=1573706959139

Pangrazio, L. (2018). Whats new about fake news? critical digital literacies in an era of fake news: Post-truth and clickbait. Education Pages, 11(1), 6-22. Doi: https://doi.org/1022235/pe.V11i1.1551

Pennycock, G., \& Rand, D. G. (2018). Lazy not biased: Susceptibility to partisan fake news is better explained by lack of reasoning than by motivated reasoning. Cognition, https://doi.org/10.1016/j.cognition.2018.06.0117

Pezzuti, L., Artistico, D., Chirumbolo, A., Picone, L., \& Dowd, S-M. (2014). The relevance of logical thinking and cognitive style to everyday problem solving among older adults. Learning and Individual Differences, 36, 1-6. https://dx.doi.org/10.1016/j.lindif.2014.07.001

Roozen, J., \& Van der Linden, S. (2019). The fake news game: Actively inoculating against the risk of misinformation. Journal of Risk Research, 22(5), 570-580. Doi:

10.1080/13669877.2018.1443491

Sezen, N., \& Bülbül, A. (2011). A scale on logical thinking abilities. Procedia Social and Behavioral Sciences, 15, 2476-2480. Doi: 10.1016/j.sbspro.2011.04.131

Scheufele, D. A., \& Krause, N. M. (2019). Science audiences, misinformation, and fake news. Proceedings of the National Academy of Sciences. 116(16), 1-8. Doi: $10.1073 /$ pnas.1805871115

Yang, Y., \&Johnson-Laird, P. N. (2001). Mental models and logical reasoning in the Gree. Journal of Experimental Psychology: Applied, 7(4), 306-316. Doi: 10.10377/1076-898X.7.4.308

Yenilmez, A., Sungur, S., \& Tekkaya, C. (2005). Investigating the studentslogical thinking abilities: The effects of gender and grade level. Haccettepe Universitesi Egitim Fakültesi Dergisi, 28(28), 2119-225. https://dergipark.org.tr/download/article-file/8773

Zhou, X., \& Zafarani, R. (2018). Fake news: A survey of research detection methods and oppurtunities. arXiv preprint.Arxiv: 181200315, 1-40. https://arxiv.org/abs/1812.00315 Zubiaga, A., Liakata, M., Procter, R., Wong Sak Hoi, G., \& Tolmie, P. (2016). Analyzing how 
INTERNATIONAL JOURNAL OF ACADEMIC RESEARCH IN BUSINESS AND SOCIAL SCIENCES

Vol. 10, No. 3, March, 2020, E-ISSN: 2222-6990 @ 2020 HRMARS

people orient to and spread rumors in social media by looking at the conversational threads. PLOS ONE. 11(3), 1-29. DOI: 10.1371/journal.pone.015098 